University of Montana

ScholarWorks at University of Montana

6-1996

\title{
Analysis of Linear Plasmid Dimers in Borrelia Burgdorferi Sensu Lato Isolates: Implications Concerning the Potential Mechanism of Linear Plasmid Replication
}

\author{
Richard T. Marconi \\ Virginia Commonwealth University \\ Sherwood Casjens \\ University of Utah \\ Ulrike G. Munderloh \\ Rocky Mountain Laboratories - NIAID \\ D. Scott Samuels \\ University of Montana - Missoula, scott.samuels@umontana.edu
}

Follow this and additional works at: https://scholarworks.umt.edu/biosci_pubs

Part of the Biology Commons

Let us know how access to this document benefits you.

\section{Recommended Citation}

Marconi, Richard T.; Casjens, Sherwood; Munderloh, Ulrike G.; and Samuels, D. Scott, "Analysis of Linear

Plasmid Dimers in Borrelia Burgdorferi Sensu Lato Isolates: Implications Concerning the Potential Mechanism of Linear Plasmid Replication" (1996). Biological Sciences Faculty Publications. 329.

https://scholarworks.umt.edu/biosci_pubs/329

This Article is brought to you for free and open access by the Biological Sciences at ScholarWorks at University of Montana. It has been accepted for inclusion in Biological Sciences Faculty Publications by an authorized administrator of ScholarWorks at University of Montana. For more information, please contact

scholarworks@mso.umt.edu. 


\section{Analysis of linear plasmid dimers in Borrelia burgdorferi sensu lato isolates: implications concerning the potential mechanism of linear plasmid replication.}

R T Marconi, S Casjens, U G Munderloh and D S Samuels J. Bacteriol. 1996, 178(11):3357.

Updated information and services can be found at:

http://jb.asm.org/content/178/11/3357

These include:

CONTENT ALERTS Receive: RSS Feeds, eTOCs, free email alerts (when new articles cite this article), more» 


\title{
Analysis of Linear Plasmid Dimers in Borrelia burgdorferi Sensu Lato Isolates: Implications Concerning the Potential Mechanism of Linear Plasmid Replication
}

\author{
RICHARD T. MARCONI ${ }^{1 *}$ SHERWOOD CASJENS, ${ }^{2}$ ULRIKE G. MUNDERLOH, ${ }^{3}$ \\ AND D. SCOTT SAMUELS ${ }^{4} \dagger$ \\ Department of Microbiology and Immunology, Medical College of Virginia, Virginia Commonwealth University, \\ Richmond, Virginia 23298-0678'; Department of Oncological Sciences, University of Utah Medical Center, \\ Salt Lake City, Utah 84132²; Department of Entomology, University of Minnesota, St. Paul, \\ Minnesota 551083; and Microscopy Branch, Rocky Mountain Laboratories, National \\ Institute of Allergy and Infectious Diseases, Hamilton, Montana 59840 4
}

Received 11 January 1996/Accepted 28 March 1996

\begin{abstract}
The Borrelia genome is composed of a linear chromosome and a number of variable circular and linear plasmids. Atypically large linear plasmids of 92 to $105 \mathrm{~kb}$ have been identified in several Borrelia burgdorferi sensu lato isolates and characterized. These plasmids carry the $p 27$ and $o s p A B$ genes, which in other isolates reside on a 50-kb plasmid. Here we demonstrate that these plasmids are dimers of the 50-kb osp $A B$ plasmid (pAB50). The 94-kb plasmid from isolate VS116, pVS94, was an exception and did not hybridize with any plasmid gene probes. When this plasmid was used as a probe, homologous sequences in other isolates were not detected, suggesting that it is unique to isolate VS116. These analyses provide insight into the mechanism of linear plasmid replication and the mechanisms by which plasmid variability can arise.
\end{abstract}

Lyme disease, a tick-borne zoonosis $(5,7,36,37)$, is caused by Borrelia burgdorferi, Borrelia garinii, and Borrelia afzelii (1, 6, 19, 20, 38). Related species of uncertain pathogenic potential, i.e., Borrelia japonica (18) and Borrelia andersonii (21), have also been identified. These five species are collectively referred to as B. burgdorferi sensu lato (BBsl). The BBsl genome is composed of variable linear and circular plasmids $(15,30)$ and a linear chromosome (11). The $\operatorname{sp} A B$ operon is carried on the largest of the linear plasmids, which ranges from 48 to $60 \mathrm{~kb}$ (31). We refer to this variably sized plasmid as the $50-\mathrm{kb}$ osp $A B$ plasmid or pAB50. The importance of the BBsl plasmids is underscored by the fact that they are present in all isolates and that they carry genes encoding metabolic enzymes (24). In view of this, the extent of plasmid variability among isolates is surprising. The significance of and the mechanisms involved in generating plasmid variability are not completely understood. Plasmid loss (32), recombination $(17,22,28)$, and lateral transfer of plasmids among BBsl species (22) have been demonstrated to be contributing processes. Here we demonstrate that linear plasmid dimer formation also contributes to plasmid variability and discuss how these findings may provide information concerning the mechanisms of linear plasmid replication.

Bacterial isolates analyzed in this study were cultivated at $34^{\circ} \mathrm{C}$ in BSK-H (Sigma) supplemented with $6 \%$ rabbit serum. Pulsed-field gel electrophoresis (PFGE) was performed to analyze plasmid content as previously described (21). Several isolates carrying $92-$ to $105-\mathrm{kb}$ plasmids, 40 to $50 \mathrm{~kb}$ larger than those typically observed $(2-4,8,16,22,31-35,39)$, were identified (Table 1). Only B. burgdorferi R100 had been previously shown to carry a plasmid in this size range (26). Southern blot analyses with an $0 s p A$ probe (ospA-5'-GGCTGCTAACATTTTGCTTACATGC) revealed that the $\operatorname{osp} A B$ operon was carried by the large plasmids in IKA2, HO14 (Fig. 1), BO23, and $\mathrm{R} 100$ and by a $50-\mathrm{kb}$ plasmid in VS116 (data not shown). In IKA2, a second plasmid of $47 \mathrm{~kb}$ also bound the probe (Fig. 1); however, after continued in vitro cultivation, this plasmid was lost and an $\operatorname{csp} A B$-hybridizing plasmid of $105 \mathrm{~kb}$ appeared (see plasmid profile in Fig. 3A, lane 3). In other isolates the large plasmids were stable with cultivation over 4 months.

TABLE 1. Description of BBsl isolates and sizes of their osp $A B$-carrying plasmids

\begin{tabular}{lllc}
\hline \multicolumn{1}{c}{ Isolate } & \multicolumn{1}{c}{$\begin{array}{c}\text { Geographic } \\
\text { origin }\end{array}$} & \multicolumn{1}{c}{$\begin{array}{c}\text { Biological origin } \\
\text { plasmid size }(\mathrm{kb})\end{array}$} \\
\hline B. burgdorferi Sh-2-82 & United States & Ixodes scapularis tick & 50 \\
B. burgdorferi R100 & United States & Hamster reisolate, originally from an Ixodes scapularis tick & 92 \\
B. afzelii BO23 & Germany & Human skin isolate & 98 \\
B. japonica IKA2 & Japan & Ixodes ovatus tick & $47,94,105^{a}$ \\
B. japonica HO14 & Japan & Ixodes ovatus tick & 105 \\
VS116 & Switzerland & Ixodes ricinus tick & 94 \\
\hline
\end{tabular}

${ }^{a}$ The species of $\operatorname{osp} A B$-hybridizing plasmid present in this isolate changed with in vitro cultivation. For discussion see the text.

${ }^{b}$ The species identity of this isolate remains unresolved. Recent data suggest that it may be a member of a newly described genospecies within the BBsl complex (27).

\footnotetext{
* Corresponding author.

$\uparrow$ Present address: Division of Biological Sciences, University of Montana, Missoula, MT 59812.
} 


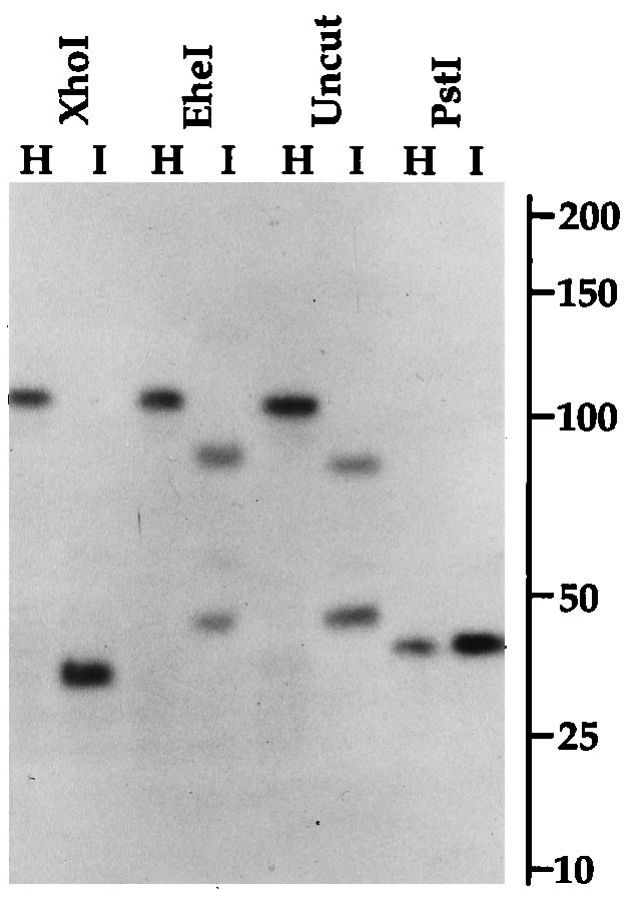

FIG. 1. Restriction and Southern blot analysis of plasmids in B. japonica isolates. H and I signify isolates HO14 and IKA2, respectively. The restriction enzymes used are indicated above the lanes, and molecular weight markers (in kilobases) are on the right. The blot was probed with an oligonucleotide directed at the osp $A$ gene (see text). All methods were as previously described (23).

Probes to other targets on pAB50 were used in hybridization analyses to determine if an extended portion of this plasmid is carried by the large plasmids. A PCR-generated p27 gene probe (amplified from $B$. garinii VSBP [GenBank accession
TABLE 2. Size and densitometry analysis of pLH1 restriction fragments

\begin{tabular}{ccccccc}
\hline $\begin{array}{c}\text { Fragment } \\
\text { designa- } \\
\text { tion }^{a}\end{array}$ & \multicolumn{5}{c}{ Restriction fragment sizes and relative densitometry values ${ }^{b}$} \\
\cline { 2 - 7 } & MluI & Pst $\mathrm{I}$ & PmeI & Bam HI & SalI & Sma I \\
\hline A & 80 & $38(2.1 \pm 0.4)$ & $32(1.0)$ & 79 & $45(1.0)$ & 78 \\
B & 12 & $27(1.0)$ & $26(2.2 \pm 0.2)$ & 9.5 & $29(1.8 \pm 0.5)$ & 14 \\
C & & & 3.5 & 3.0 & & \\
D & & & 2.5 & & &
\end{tabular}

${ }^{a}$ The fragment designations (i.e., A to D) for each restriction enzyme are as indicated in Fig. 2.

${ }^{b}$ Fragment sizes are in kilobases. Fragments smaller than $2.5 \mathrm{~kb}$ were not analyzed. The values in parentheses are the relative intensities $( \pm$ the standard deviations) as described in the text. In each case, the central fragment of the plasmid obtained (refer to Fig. 2) was assigned a value of 1.0. Relative intensities were not determined for fragments obtained by digestion with $M l u \mathrm{I}, B a m \mathrm{H} 1$, or SmaI. The values with standard deviations are means of three independent determinations.

number M85216]) and p2H14, a cloned fragment of pAB50 (29) from $B$. burgdorferi Sh-2-82, were used as probes. These probes bound the large plasmids of all isolates except VS116, in which they hybridized to a 50-kb plasmid (data not shown). The map locations of p27 and p2H14 on the $50-\mathrm{kb}$ plasmid of Sh-2-82, pLS1, were determined (Fig. 2). Since these probe target sites are widely separated, it can be concluded that the large plasmids carry a complete copy of pAB50 and that the composition of pVS94 is distinct from that of the other large plasmids. We refer to the $p 27$ and $\operatorname{ssp} A B$ ends of these plasmids as the tail and head ends, respectively.

To determine if the $\sim 100-\mathrm{kb}$ plasmids are dimers of pAB50, the large plasmid from HO14, pLH1, was excised from agarose gels, digested with various restriction enzymes, and analyzed by PFGE. Restriction digestions were performed as instructed by the supplier, and PFGE was performed in $1 \%$ agarose gels as previously described (8). With each enzyme tested, the sum of

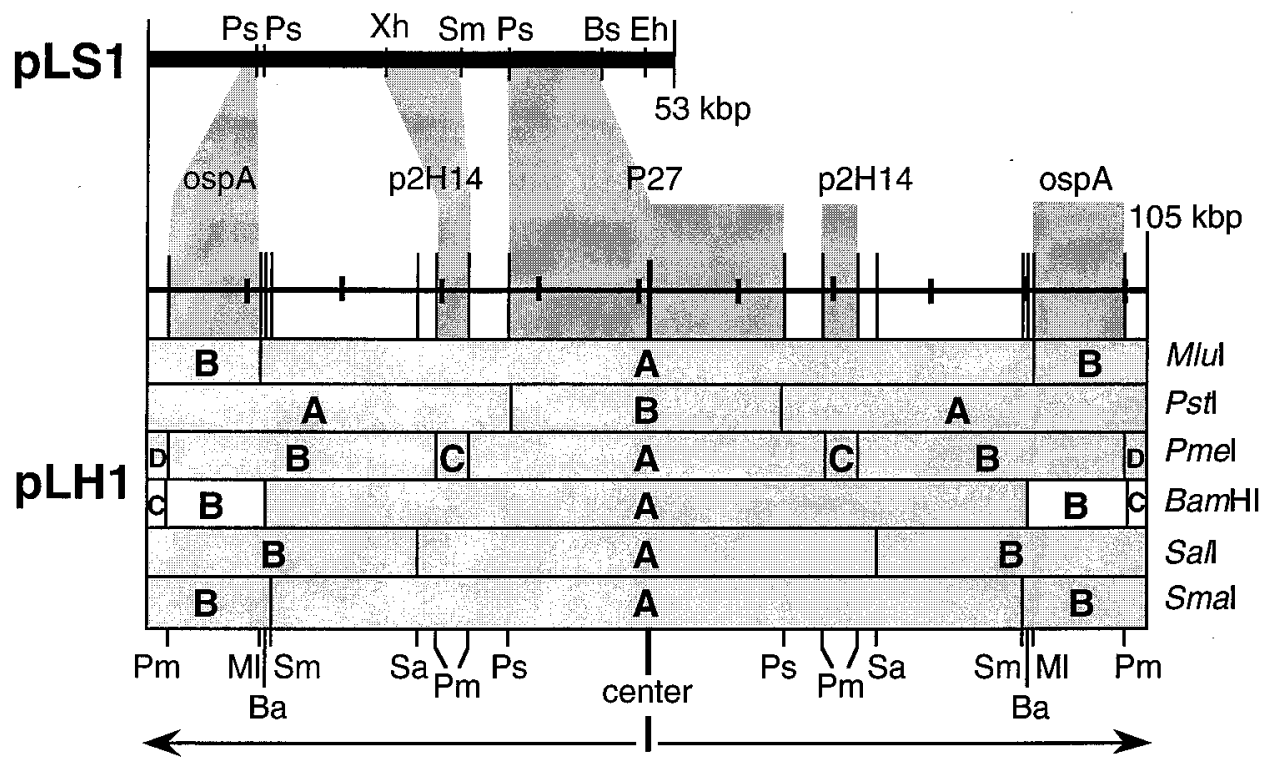

FIG. 2. Physical and genetic maps of pLH1 from $B$. japonica HO14. The physical map was constructed through single and double restriction digests as previously described (9). The black bar at the top of the figure shows the physical map of the 50-kb ospAB plasmid, pLS1, from B. burgdorferi Sh-2-82. The restriction maps of the $B$. japonica $\mathrm{HO} 14$ plasmid pLH1 are shown, with the enzymes used to generate them listed on the right. The lighter-gray and white rectangles indicate fragments that have been unequivocally ordered and that have not been ordered, respectively. The darker-gray regions are the map locations determined for the $o s p A B$ and $\mathrm{P} 27$ genes. Restriction site abbreviations are as follows: Ps, PstI; Xh, XhoI; Sm, SmaI; Bs, BssHI; Eh, EheI; Pm, PmeI; Ml, MluI; Ba, BamHI; and Sa, SalI. For each individual digestion, the fragments have been designated with letters in order to facilitate inspection of the data presented in Table 2. 
A

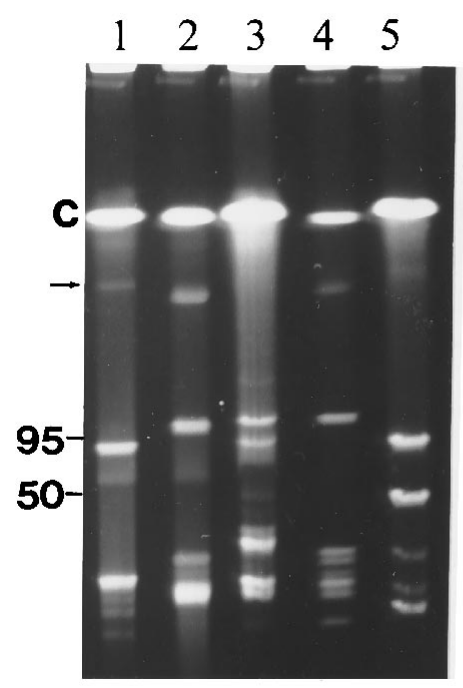

B

$\begin{array}{lllll}1 & 2 & 3 & 4 & 5\end{array}$
the probe. The PFGE-fractionated DNA was stained with ethidium bromide (A) and then blotted and probed with random-primed labeled pVS94 (B). The isolates tested included B. burgdorferi R100, B. afzelii BO23, B. japonica IKA2, B. japonica HO14, and BBsl isolate VS116 (lanes 1 to 5, respectively). Molecular weight markers are indicated on the left (in kilobases). The position of the linear chromosome is indicated by a $\mathrm{C}$, and the general region to which some of the circular plasmids migrate is indicated by the arrow.

the sizes of the restriction fragments was found to be less than the size of the undigested plasmid (Table 2). These results suggest that there are comigrating restriction fragments. Consistent with this, densitometric scanning of photographic negatives of the stained gels (Table 2) revealed that all fragments were not present in equimolar amounts. For example, the two Pst I fragments of 38 and $27 \mathrm{~kb}$ occur at a ratio of $2: 1$. If the $38-\mathrm{kb}$ fragment is counted twice, the sum is close to the size of the uncut plasmid. In addition, only a single osp $A B$-hybridizing fragment was detected for each digestion. These observations are consistent with a dimeric plasmid with its monomers linked

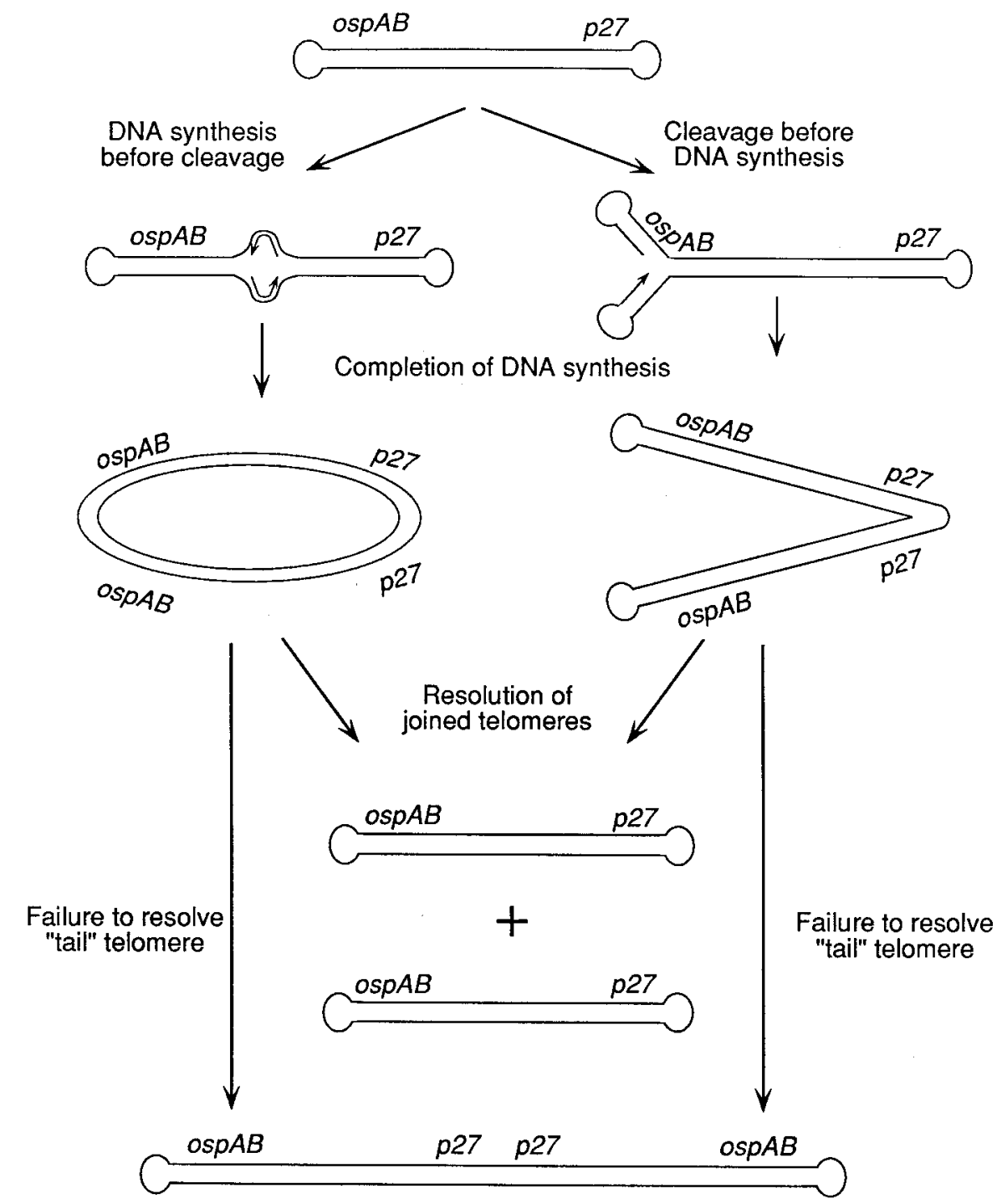

FIG. 4. Potential models for the mechanism of origin of the osp $A B$ linear plasmid dimers. The model presented in the right half of the figure is similar to that proposed for vaccinia virus replication (25). 
tail to tail. The validity of the tail-to-tail model was confirmed by restriction analysis and subsequent construction of a pLH1 physical map (Fig. 2). Restriction and Southern analyses suggest a similar structure for the large plasmids of IKA2 (Fig. 2) and $\mathrm{BO} 23$ (data not shown).

In contrast to the other large plasmids, pVS94 did not hybridize with any pAB50-targeting probes. pAB50 probes instead hybridized with a $50-\mathrm{kb}$ plasmid in isolate VS116. To determine if pVS94 was a dimer of other BBsl plasmids, it was purified and used as a probe in Southern analysis. pVS94 hybridized only with itself, indicating that it is unique to isolate VS116 (Fig. 3). VS116 may belong to a previously unrecognized Borrelia species (27); hence, pVS94 may represent a species-specific plasmid. This analysis indicates that it cannot be inferred that all BBsl large plasmids have arisen via dimer formation.

The plasmid dimers may have arisen through recombination or from failed segregation after replication. While recombination-mediated dimer formation cannot be ruled out, it seems unlikely in view of the specific orientation of the monomers in these dimers. Dimers generated by recombination could be linked anywhere along the monomers since they are homologous throughout. Alternatively, the dimers may have arisen because of a replication error. It has been suggested that some BBsl plasmids may replicate by the rolling circle replication mechanism (10). However, dimers resulting from failed segregation after rolling circle replication could only be oriented head to tail. We found no evidence of head-to-tail structures. The BBsl plasmids may replicate by a mechanism like that proposed for the similarly structured vaccinia virus. Several models have been proposed (25) for vaccinia virus replication which differ with regard to the timing of telomeric cleavage or nicking and as to whether replication initiates from one or both telomeres. If the hairpin loop at one telomere is nicked and initiation proceeds from that end, then it is possible to form head-to-head or tail-to-tail junctional intermediates, depending on the end from which initiation occurs. By this model, if the pLH1 tail-to-tail dimer arose from failed segregation, then replication initiation would have to have occurred from the head telomere as depicted in Fig. 4 (right). However, it cannot be ruled out that tail-to-tail dimers could occur from a circular replication intermediate if segregation required independent cleavage events at each telomere junction but cleavage of the tail telomeres failed to occur because of an unidentified lesion (point mutation, etc.) (Fig. 4, left). On the basis of identification of circular-to-linear interconversion of a $180-\mathrm{kb}$ plasmid, it has been proposed that replication of the Borrelia hermsii plasmids proceeds through a monomeric circular intermediate (12). The structures of the dimers presented here are not consistent with a replication model involving a monomeric circular intermediate. Any dimers that arose through this potential mechanism of replication would be oriented head to tail.

The telomeric sequences of some BBsl linear plasmids, including pAB50, and the African swine fever virus, an iridovirus, exhibit some homology $(14,15)$. Hinnebusch et al. (14) suggested the possibility of interkingdom genetic transfer between African swine fever virus and Borrelia duttonii, both of which are carried by the same arthropod vector, Ornithodoros moubata. Lateral plasmid exchange has been demonstrated among BBsl species, indicating that they can take up exogenous DNA (22). It is possible, as originally suggested by Hinnebusch and Barbour (13), that the Borrelia species may have stably incorporated linear viral DNA into the BBsl genome. While we can only speculate as to the molecular origins of these dimers and the linear plasmid component of the BBsl genome, studies such as that presented here and the recent work of Ferdows et al. (12) are important because they increase our understanding of the molecular mechanisms that influence genome organization, plasmid stability, linear plasmid replication, and evolution in Borrelia species.

We thank Patti Rosa and Kit Tilly for supplying the p2H14 probe and for critical evaluation of the manuscript.

During the early stages of this study, R.T.M. was supported by the National Institutes of Health. R.T.M. is presently supported in part by grants from the A.D. Williams Foundation and the Jeffress Trust, and S.C. is supported in part by a grant from the Associated Regional and University Pathologists.

\section{REFERENCES}

1. Baranton, G., D. Postic, I. Saint Girons, P. Boerlin, J.-C. Piffaretti, M. Assous, and P. A. D. Grimont. 1992. Delineation of Borrelia burgdorferi sensu stricto, Borrelia garinii sp. nov., and group VS461 associated with Lyme borreliosis. Int. J. Syst. Bacteriol. 42:378-383.

2. Barbour, A. G. 1988. Plasmid analysis of Borrelia burgdorferi, the Lyme disease agent. J. Clin. Microbiol. 26:475-478.

3. Barbour, A. G., and C. F. Garon. 1988. The genes encoding the major surface proteins of Borrelia burgdorferi are located on a plasmid. Ann. N. Y. Acad. Sci. 539:144-153.

4. Baril, C., C. Richaud, G. Baranton, and I. Saint Girons. 1989. Linear chromosome of Borrelia burgdorferi. Res. Microbiol. 140:507-516.

5. Benach, J. L., E. M. Bosler, J. P. Hanrahan, J. L. Coleman, T. F. Bast, G. S. Habicht, D. J. Cameron, J. L. Ziegler, A. G. Barbour, W. Burgdorfer, R. Edelman, and R. A. Kaslow. 1983. Spirochetes isolated from the blood of two patients with Lyme disease. N. Engl. J. Med. 308:740-742.

6. Boerlin, P., O. Peter, A.-G. Bretz, D. Postic, G. Baranton, and J.-C. Piffaretti 1992. Population genetic analysis of Borrelia burgdorferi isolates by multilocus enzyme electrophoresis. Infect. Immun. 60:1677-1683.

7. Burgdorfer, W., A. G. Barbour, S. F. Hayes, J. L. Benach, E. Grunwaldt, and J. P. Davis. 1982. Lyme disease-a tick-borne spirochetosis? Science 216: 1317-1319.

8. Casjens, S., M. Delange, H. L. Ley III, P. Rosa, and W. M. Huang. 1995 Linear chromosomes of Lyme disease agent spirochetes: genetic diversity and conservation of gene order. J. Bacteriol. 177:2769-2780.

9. Casjens, S., and W. M. Huang. 1993. Linear chromosomal physical and genetic map of Borrelia burgdorferi, the Lyme disease agent. Mol. Microbiol. 8:967-980.

10. Dunn, J. J., S. R. Buchstein, L.-L. Butler, S. Fisenne, D. S. Polin, B. N. Lade, and B. J. Luft. 1994. Complete nucleotide sequence of a circular plasmid from the Lyme disease spirochete, Borrelia burgdorferi. J. Bacteriol. 176: 2706-2717.

11. Ferdows, M. S., and A. G. Barbour. 1989. Megabase-sized linear DNA in the bacterium Borrelia burgdorferi, the Lyme disease agent. Proc. Natl. Acad. Sci. USA 86:5969-5973.

12. Ferdows, M. S., P. Serwer, G. A. Griess, S. J. Norris, and A. G. Barbour 1996. Conversion of a linear to a circular plasmid in the relapsing fever agent Borrelia hermsii. J. Bacteriol. 178:793-800.

13. Hinnebusch, J., and A. G. Barbour. 1991. Linear plasmids of Borrelia burgdorferi have a telomeric structure and sequence similar to those of a eukaryotic virus. J. Bacteriol. 173:7233-7239.

14. Hinnebusch, J., S. Bergstrom, and A. G. Barbour. 1990. Cloning and sequence analysis of linear plasmid telomeres of the bacterium Borrelia burgdorferi. Mol. Microbiol. 4:811-820.

15. Hinnebusch, J., and K. Tilly. 1993. Linear plasmids and chromosomes in bacteria. Mol. Microbiol. 10:917-922.

16. Hughes, C. A. N., C. B. Kodner, and R. C. Johnson. 1992. DNA analysis of Borrelia burgdorferi NCH-1, the first northcentral U.S. human Lyme disease isolate. J. Clin. Microbiol. 30:698-703.

17. Hyde, F. W., and R. C. Johnson. 1988. Characterization of a circular plasmid from Borrelia burgdorferi, etiologic agent of Lyme disease. J. Clin. Microbiol. 26:2203-2205.

18. Kawabata, H., T. Masuzawa, and Y. Yanagihara. 1993. Genomic analysis of Borrelia japonica sp. nov. isolated from Ixodes ovatus in Japan. Microbiol. Immunol. 37:843-848.

19. Marconi, R. T., and C. F. Garon. 1992. Identification of a third genomic group of Borrelia burgdorferi through signature nucleotide analysis and $16 \mathrm{~S}$ rRNA sequence determination. J. Gen. Microbiol. 138:533-536.

20. Marconi, R. T., and C. F. Garon. 1992. Phylogenetic analysis of the genus Borrelia: a comparison of North American and European isolates of Borrelia burgdorferi. J. Bacteriol. 174:241-244.

21. Marconi, R. T., D. Liveris, and I. Schwartz. 1995. Identification of nove insertion elements, restriction fragment length polymorphism patterns, and discontinuous 23S rRNA in Lyme disease spirochetes: phylogenetic analyses 
of rRNA genes and their intergenic spacers in Borrelia japonica sp. nov. and genomic group 21038 (Borrelia andersonii sp. nov.) isolates. J. Clin. Microbiol. 33:2427-2434.

22. Marconi, R. T., D. S. Samuels, R. K. Landry, and C. F. Garon. 1994. Analysis of the distribution and molecular heterogeneity of the $\operatorname{sip} D$ gene among the Lyme disease spirochetes: evidence for lateral gene exchange. J. Bacteriol. 176:4572-4582.

23. Marconi, R. T., D. S. Samuels, T. G. Schwan, and C. F. Garon. 1993. Identification of a protein in several Borrelia species which is related to OspC of the Lyme disease spirochetes. J. Clin. Microbiol. 31:2577-2583.

24. Margolis, N., D. Hogan, K. Tilly, and P. A. Rosa. 1994. Plasmid location of Borrelia purine biosynthesis gene homologs. J. Bacteriol. 176:6427-6432.

25. Moss, B., E. Winters, and E. V. Jones. 1983. Proceedings of the 1983 UCLA Symposium on the Mechanics of DNA Replication and Recombination, $p$. 449-461.

26. Munderloh, U. G., V. J. Dioh, A. M. Fallon, and T. J. Kurtti. 1993. Plasmid modification in a tick-borne pathogen, Borrelia burgdorferi, cocultured with tick cells. Insect. Mol. Biol. 14:195-203.

27. Postic, D., M. V. Assous, P. A. D. Grimont, and G. Baranton. 1994. Diversity of Borrelia burgdorferi sensu lato evidenced by restriction fragment length polymorphism of $r r f(5 \mathrm{~S})-r r l(23 \mathrm{~S})$ intergenic spacer amplicons. Int. J. Syst. Bacteriol. 44:743-752.

28. Rosa, P. A., T. Schwan, and D. Hogan. 1992. Recombination between genes encoding major outer surface proteins A and B of Borrelia burgdorferi. Mol. Microbiol. 6:3031-3040.

29. Rosa, P. A., and T. G. Schwan. 1989. A specific and sensitive assay for the Lyme disease spirochete Borrelia burgdorferi using the polymerase chain reaction. J. Infect. Dis. 160:1018-1029.

30. Saint Girons, I., I. G. Old, and B. E. Davidson. 1994. Molecular biology of the Borrelia, bacteria with linear replicons. Microbiology 140:1803-1816.

31. Samuels, D. S., R. T. Marconi, and C. F. Garon. 1993. Variation in the size of the $\operatorname{sp} A$-containing linear plasmid, but not the linear chromosome, among the three Borrelia species associated with Lyme disease. J. Gen. Microbiol. 139:2445-2449.

32. Schwan, T. G., W. Burgdorfer, and C. F. Garon. 1988. Changes in infectivity and plasmid profile of the Lyme disease spirochete, Borrelia burgdorferi, as a result of in vitro cultivation. Infect. Immun. 56:1831-1836.

33. Schwan, T. G., M. E. Schrumpf, R. H. Karstens, J. R. Clover, J. Wong, M. Daugherty, M. Struthers, and P. A. Rosa. 1993. Distribution and molecular analysis of Lyme disease spirochetes, Borrelia burgdorferi, isolated from ticks throughout California. J. Clin. Microbiol. 31:3096-3108.

34. Simpson, W. J., C. F. Garon, and T. G. Schwan. 1990. Analysis of supercoiled circular plasmids in infectious and non-infectious Borrelia burgdorferi. Microb. Pathog. 8:109-118.

35. Stålhammar-Carlemalm, M., E. Jenny, L. Gern, A. Aeschlimann, and J. Meyer. 1990. Plasmid analysis and restriction fragment length polymorphisms of chromosomal DNA allow a distinction between Borrelia burgdor feri strains. Zentralbl. Bakteriol. 274:28-39.

36. Steere, A. C., R. L. Grodzicki, A. N. Kornblatt, J. E. Craft, A. G. Barbour, W. Burgdorfer, G. P. Schmid, E. Johnson, and S. E. Malawista. 1983. The spirochetal etiology of Lyme disease. N. Engl. J. Med. 308:733-740.

37. Steere, A. C., S. E. Malawista, D. R. Snydman, R. E. Shope, W. A. Andiman, M. R. Ross, and F. M. Steele. 1977. Lyme arthritis: an epidemic of oligoarticular arthritis in children and adults in three Connecticut communities. Arthritis Rheum. 20:7-17.

38. Welsh, J., C. Pretzman, D. Postic, I. Saint Girons, G. Baranton, and M McClelland. 1992. Genomic fingerprinting by arbitrarily primed polymerase chain reaction resolves Borrelia burgdorferi into three distinct phyletic groups. Int. J. Syst. Bacteriol. 42:370-377.

39. Xu, Y., and R. C. Johnson. 1995. Analysis and comparison of plasmid profiles of Borrelia burgdorferi sensu lato strains. J. Clin. Microbiol. 33:2679-2685. 